\section{ROYAL SOCIETY OF CANADA ANNUAL MEETING}

$\mathrm{T}$ HE meeting of the Royal Society of Canada for 1945 was held at Queen's University, Kingston, Ontario, during May 20-23, under the chairmanship of the president, Prof. J. K. Robertson, professor of physics at Queen's University. In the scientific sections, one hundred and four fellows, and half as many guests, were in attendance.

In addition to sectional and business meetings, there were two largely attended evening meetings. On the evening of May 21, the Society's medals were presented. Prof. R. B. Thomson, University of Toronto, received the Flavelle Medal as a tribute to his work on the comparative anatomy and physiology of plants. The Henry Marshal Tory Medal was presented to Dr. Otto Maass, professor of physical chemistry at MeGill University, assistant to the president of the National Research Council, and director of chemical warfare and smoke for the Department of National Defence. He was hailed as a man possessed of experimental skill and scientific imagination, with a fondness for hazardous experiment, who has played a leading part in planning chemical research in Canada since the outbreak of the War. The Willet G. Miller Medal was given to Dr. M. E. Wilson, Geological Survey, Ottawa, who, conspicuous among Precambrian geologists of the world, has done much in Canada in the development of mining. The Lorne Pierce Medal was awarded to L'Abbé Felix Antoine Savard, Laval University, and the Tyrell Medal to Prof. F. Landon, University of Western Ontario.

After the presentation of medals, Prof. J. K. Robertson delivered his presidential address on "Continuity and Discontinuity". The paper was divided into two parts : a discussion of the progress of philosophical opinion down to the eighteenth century, followed by an assessment of the development of the two conceptions by physicists up to the present day. Recognizing that "present-day physics continues to demonstrate the inter-play of continuity and discontinuity", he concludes that "The modern physicist no longer accepts a materialistic philosophy and no longer assumes that, as time goes on, he will learn more and more about the ultimate details of a real objective world. His advances have shown him that measurements and observations can not give him exact knowledge beyond a certain stage, and hence for him, what is beyond has no meaning. His aim now is the more modest one of describing facts and observations in terms of correlating laws, which in the last analysis can be expressed accurately only by mathematical symbols".

On the evening of May 22, following a complimentary dinner given by the Mayor and City Council of Kingston, a popular lecture, "Biological Control of Insect and Plant Pests", was given by Dr. W. R. Thompson, Imperial Parasite Service, Belleville, Ontario. This paper so impressed the audience that a resolution was passed at a general meeting next day expressing to the Imperial Institute of Entomology its appreciation of the work done in Canada during the War, and asking that arrangements be made for its continuation.

In Section I, twenty-one papers were presented on subjects of historical or literary interest in French Canada.

In Section II, the presidential address by Prof.
W. H. Alexander was a provocative discussion of some obvious inoompatibilities of temperament as between the ideals of a genuine education and the spirit of the ultra-democratic State as suggested by Plato's "Apology to Socrates". Papers were read in the fields of literature, philosophy, history and the social sciences. Anthropology and archæology were represented by papers on "The Distribution of Rubbed Slate Instruments in Eastern Canada" by Dr. Douglas Leechman, and by the myth of "Bear Mother" by Dr. Marius Barbeau. A timely paper was presented by Prof. R. Flenley, "The Results of the Reformation in Germany".

In Section III, the most important feature of the meeting was a symposium on the dimensions of the galaxy. This subject was first treated very ably by Dr. Helen Sawyer Hogg from the point of view of the observations on globular clusters. Dr. C. S. Beals dealt with the obscuring matter between the stars and its influence on estimates of galactic dimensions. These papers led up to the presidential address by Dr. J. A. Pearce, of the Dominion Astrophysical Observatory, entitled "The Dimensions of the Galaxy as Derived from Studies of Galactic Rotation", in which he reviewed the history of the subject from the time of Herschel to the most recent estimates.

Thirty-five other papers were presented to this Section, ten by title. A notable series of ten chemical papers was presented by Prof. Paul-E. Gagnon, of Laval University, Quebec, ranging from the synthesis of amino-acids to the technology of charcoal, and exhibiting the great aetivity in chemistry at that institution. Prof. William Ure, of the University of British Columbia, described the mechanism of the 'flotation process' of concentrating ores, showing the necessity of a water-repellent layer on the surface of the mineral. Prof. J. K. Robertson, Queen's Univer. sity, described the effect of high-frequency discharges in producing patterns in thin layers of metal placed in the discharge tube. Five meteorological papers were read by members of the staff of the Meteorological Service of Canada, including a new theory of the mechanism of the 'Chinook' wind (the warm dry wind which frequently descends the eastern slope of the Rocky Mountains in Alberta) by D. H. Smith and C. E. Thompson.

Nineteen papers were presented to Section IV. In the presidential address, Dr. J. S. DeLury gave an outline of a hypothesis to explain crustal movements. In his opinion, the earth's crust is strong to a depth of 450 miles or more. Liquid rock, known as magma, and as lava when it reaches the surface, is formed in shallow levels by frictional heat generated in crustal movements, and is not inherited from a primitive molten earth. These movements are due to failure in the crust eaused by thermal contraction followed by a very protracted process of collapse.

Dr. A. W. Jolliffe presented evidence that, geologically, the north-western part of the Canadian Shield may be divided into four sub-provinces. From north to south these are : (1) Great Bear-characterized by Proterozoic formations, north-east faulting with righthand displacements, and uranium-silver-cobalt-nickel-copper mineralization; (2) Yellowknife-characterized by Archæan formations, north to northwest faulting with left-hand displacements, and gold mineralization; (3) East Arm-characterized by chiefly Proterozoic formations, north-east faulting, and copper-cobalt-nickel-gold mineralization; and (4) Taltson-by both Proterozoic and Archæan 
formations, north to north-west faulting, and silverlead-gold mineralization.

Dr. T. L. Tanton offered a theory, based on a study of conchilites and the work of W. D. Francis, suggesting the steps whereby non-living matter may have evolved into semi-living organisms, which provided the catalyser for the synthesis of protein and the conditions that induced the evolution of primeval forms of life. Dr. M. L. Keith described brucite deposits in the Rutherglen District, Ontario. Franco Rasetti reported the discovery of Middle Cambrian fossils in the Gaspé, the first recorded in the Province of Quebec. Dr. R. F. Legget described the geology of the "Shipshaw" area on the Saguenay River, and reported finding wood and other organic matter imbedded in the clay. Peter Ginn described an ultrabasic rock near Lochalsh, Ontario.

Dr. Robert Newton, president of Section $V$, in discussing the northern limits of wheat production, pointed out that wheat production in Canada is mainly confined to the southern plains region of the Prairie Provinces. Its possible northward extension concerns not only the potential world food supply, but also the feasibility of northern settlement. The longer summer days of northern latitudes are favourable to growth, but their value is reduced by association with lower temperatures. Rainfall is another important modifying factor. Moreover, the milling and baking quality of northerm wheat is generally inferior. This may not destroy its usefulness as a local food resource, but makes it unsuitable as an article of commerce.

Prof. R. B. Thomson, who was awarded the Flavelle Medal, presented a paper entitled "Food Supply and Budding or Twinning Embryogeny". Prof. Thomson believes that the view that the asexual type of embryo initiation involved in budding or twinning embryogeny is due to recent mutation is not supported by sufficient evidence; whereas that for its being an innate or constitutional potentiality is satisfactory. The expression of this potentiality, however, is generally kept under control as indicated by the prevalence of simple embryogeny (one embryo from one zygote) in the main lines of evolutionary advance. Thus the problem of accounting for the sporadic occurrence of budding or twinning at different levels in such advance is concerned with the elimination of established control. This has been effected in animals by various physical and chemical experimental procedures. Up to the present, however, little attention has been given to the influence of food supply, and some experimental and other evidence, particularly the effect of excess nutrition on the production of a free nuclear stage in embryos normally undergoing simple embryogeny, indicates the importance of giving more attention to the possibly broader significance of this factor.

Dr. W. H. Cook, director of the Division of Applied Biology of the National Research Council, discussed some of the War research projects of the Council under the title "Some Wartime Food and Supply Problems". Under war conditions the main problem in feeding eivilian or Service personnel is that of transport and distribution, complicated by the perishability of many foodstuffs. To meet the emergency, facilities had to be improvised to preserve the product, or alternatively the foodstuffs themselves had to be rendered less perishable. The dehydration of foodstuffs rich in proteins and fats was discussed in relation to the measurement and maintenance of quality and the type of deterioration that occurs. Several new chemicals required by war industry can be provided by the fermentation of starch. Reference was made to the bacterial fermentation yielding 2,3-butanediol, a material readily converted to butadiene and other chemicals.

Thirty-eight other papers on various phases of biological and medical sciences made up the programme of Section V. These included an important communication by Dr. B. P. Babkin, describing the interference of quinine bisulphate with cholinergic mechanisms in the heart and stomach of the dog, and a demonstration by Dr. C. C. Macklin that venule capacity in the lung is increased on inspiration.

Fifteen new fellows were presented, including the following in the Scientific Sections: Section III (Chemical, Mathematical and Physical Sciences): R. Brauer, E. W. Hewson, O. J. Walker ; Section IV (Geological Sciences): V. J. Okulitch, J. E. Thomson, H. V. Warren; Section V (Biological Sciences) : E. W. Crampton, J. Labarre, W. Leach, C. A. Mitchell, A. W. H. Needler, D. Y. Solandt.

Officers for 1945-46 were elected as follows: President, Prof. E. S. Moore, University of Toronto; Vice-President, Prof. H. A. Innis, University of Toronto ; President of Section I, Dr. S. Marion, Ottawa; President of Section II, Prof. D. C. Harvey, Dalhousie University, Halifax; President of Section III, Prof. C. T. Sullivan, McGill University ; President of Section IV, Dr. B. R. MacKay, Ottawa; President of Section V, Dr. B. P. Babkin, McGill University.

\section{MODE OF ACTION OF PENICILLIN}

SOME of the more recent work on the mode of $\checkmark$ action of penicillin was briefly reviewed in Nature (155, 403, March 31, 1945). Work noted there established the fact that penicillin is not merely bacteriostatic but also can actively destroy some microorganisms. This bactericidel effect appears to be exerted especially upon the young bacterial cell and upon feeding bacteria, and to be therefore conditioned by certain factors in their environment. A leading article in the Lancet $(276$, March 3,1945$)$ summarizes the facts about this question which were available up to that date.

Important recent papers have since appeared. Thus E. Chain and E. S. Duthie (Lancet, 652, May 26, 1945) point out that Fleming, in his original paper on penicillin, recorded its slow bactericidal effect on Staphylococcus and its lytic effect under certain conditions. They explain that the original statement by the Oxford workers that penicillin is mainly bacteriostatic was based on the fact that it did not affect the oxygen uptake of resting Staphylococcus, for large numbers of viable colonies were found after incubation with penicillin in Ringer solution for twenty-four hours. They then review work done in the United States, which demonstrated that penicillin is bactericidal, but that it is not so under unfavourable conditions (such as low temperature or exhausted media) and that its bactericidal effect can be increased by substances which enhance bacterial growth and decreased by substances which interfere with bacterial growth (for example, sulphadiazine). From the results of their own work recorded in this paper, Chain and Duthie conclude that, during the resting phase of Staphylococcus, even large concentrations of penicillin have no effect on the oxygen 